\title{
IMPLEMENTATION OF REGULATIONS BRING FOODS TO SCHOOL TO CONSUMPTIVE BEHAVIOR OF ELEMENTARY SCHOOL STUDENTS IN PURWAKARTA
}

\author{
Deri Fadly Pratama1, Deden H. Altaftazani ${ }^{2}$, Anugrah R. Firdaus ${ }^{3}$ \\ ${ }^{1}$ Institut Keguruan dan Ilmu Pendidikan Siliwangi \\ ${ }^{2}$ Institut Keguruan dan Ilmu Pendidikan Siliwangi \\ ${ }^{3}$ Institut Keguruan dan Ilmu Pendidikan Siliwangi \\ ${ }^{1}$ fadly-pratama@ikipsiliwangi.ac.id , ${ }^{2}$ deden@ikipsiliwangi.ac.id , ${ }^{3}$ anugrah@ikipsiliwangi.ac.id
}

\begin{abstract}
This research is motivated by the issuance of government policies relating to the progress of the world of education. The purpose of this study is to examine the implementation of the policy on consumptive behavior among elementary school students. The research method used is a case study. Subjects in the study were 100 students who were divided into 3 (three) classes at the high class level at SDN Ciseureuh Kahuripan Pajajaran Purwakarta district, as well as providing relevant counseling to teachers, parents, community leaders and related stakeholders. The instrument used to measure the level of implementation in this regulatory policy is the observation and interview sheets while for the assessment of consumptive behavior is a matter of multiple choice, observation sheets and questionnaires given. The treatment given to stakeholders is counseling that optimizes the implementation of regulations to bring provisions to schools in the form of rules and policy levels using a persuasive approach. The results showed that the implementation of regulations bringing provision to schools initiated by Purwakarta district government significantly decreased the consumptive nature compared to students who did not receive treatment from the government regulations. Thus it can be concluded that the implementation of the regulation of bringing provisions to schools initiated by the Purwakarta district government can suppress the consumptive nature of elementary school students..
\end{abstract}

Keywords: Government policies, consumptive behavior and bringing provisions to schools

\begin{abstract}
Abstrak
Penelitian ini dilatar belakangi oleh terbitnya kebijakan pemerintah yang berkaitan dengan kemajuan dunia pendidikan. Tujuan penelitian ini adalah mengkaji implementasi kebijakan tersebut terhadap perilaku konsumtif di kalangan siswa Sekolah Dasar. Metode penelitian yang digunakan adalah studi kasus. Subjek dalam penelitian adalah 100 siswa yang terbagi menjadi 3 (tiga) kelas pada tataran kelas tinggi di SDN Ciseureuh Kahuripan Pajajaran kabupaten Purwakarta, beserta memberikan penyuluhan terkait kepada para guru, orang tua siswa, tokoh masyarakat dan stake holder terkait. Instrumen yang digunakan untuk mengukur tingkat implementasi dalam kebijakan peraturan ini adalah lembar observasi dan wawancara sedangkan untuk penilaian terhadap perilaku konsumtif adalah soal pilihan ganda, lembar observasi dan angket yang diberikan. Perlakuan yang diberikan kepada para pelaku stake holder adalah penyuluhan yang mengoptimalkan implementasi peraturan membawa bekal ke sekolah berupa aturan dan tataran kebijakan dengan menggunakan pendekatan persuasif. Hasil penelitian menunjukkan bahwa implementasi peraturan membawa bekal ke sekolah yang digagas oleh pemerintah kabupaten purwakarta meningkat secara signifikan menurunkan sifat konsumtif dibandingkan dengan siswa yang tidak mendapatkan perlakuan dari peraturan pemerintahan tersebut. Dengan demikian dapat disimpulkan bahwa implementasi peraturan membawa bekal ke sekolah yang digagas oleh pemerintah kabupaten purwakarta dapat menekan sifat konsumtif siswa sekolah dasar.
\end{abstract}

Kata Kunci: Kebijakan Pemerintah, Perilaku Konsumtif, Membawa bekal ke sekolah

\section{INTRODUCTION}


Current technological developments that tend to make it easier for everyone to buy/have something. The condition is like two blades. On one side this condition is very useful because it will facilitate humans in carrying out various activities and meeting their needs. But on the other hand, this condition will make everyone buy all sorts of things without considering the financial condition. In other words, people will have the desire to buy things because the process is so easy. Previous research conducted by Setiawan and Ibnu (2016) on the effect of food service delivery on the formation of high school students' consumptive attitudes, and research by Ridwan (2017) on the use of food service on student consumptive attitudes. From some of the results of these studies it can be concluded that the ease of online services and food delivery increases the consumptive attitude of students and students. Seeing the problems above, of course there must be an effort to control consumer behavior. There are many local governments that already understand this condition. One of them is Purwakarta Regency Government. Purwakarta Regency Government issued Purwakarta Regent Regulation Number 69 of 2015 concerning Character Education, precisely in Chapter VII regarding the obligation to bring food / drinks to school. It is expected that with the enactment of the regent's regulations, students will be accustomed to bringing provisions from home so that the habit of buying food (snacks) can be suppressed and will have an impact on decreasing consumer behavior.

\section{Consumptive Behavior}

Consumptive behavior is the desire to buy or have something that is basically less needed. The term "behavior" has the meaning of individual responses or reactions to stimuli or the environment (KBBI on-line, 2016). While "consumptive" has the meaning of consumption (only using, not producing itself) (KBBI on-line, 2016). Understanding consumptive, in general, is to buy and use a variety of goods or services excessively and with wasteful behavior that prioritizes desires without regard to needs when viewed in terms of priorities or can also be referred to as excessive lifestyle (Bagas et al 2018).

So consumptive behavior is an individual/community activity to consume or buy an item because of a desire/stimulus. Consumptiveism can be defined as a way of life for someone who has the desire to buy, own and use an item or service that is basically less or not needed and leads to an excessive lifestyle.

\section{Peraturan Bupati no 69 tahun 2015}

Implementation Of Regulations Bring Foods To School To Consumptive Behavior Of Elementary School Students In Purwakarta 77 
Purwakarta Regent Regulation on Bringing Food / Beverage to Schools is regulated in Peraturan Bupati no 69 tahun 2015 concerning Character Education. Directions for bringing food/drink supplies from home are regulated in chapter VII, chapters 13-18. The following is the sound of each article:

1. Article 13 (1) To familiarize a healthy and economical life, each student is required to bring food and drink from home to school. (2) Food and drinks as referred to in paragraph (1) must meet the nutritional needs of the Student during school.

2. Article 14 (1) Food brought to school must be put into a container such as a basket. (2) Time to eat, which is during recess or other hours that do not interfere with learning activities. (3) Places for eating activities can be done in classrooms or other places with assistance from the teacher. (4) The implementation of eating activities must pay attention to hygiene and hygiene aspects such as washing hands before and after eating and taking out the trash in its place.

3. Article 15 To foster a sense of togetherness, loyal friends and caring, teachers must provide direction so that students give and share with each other.

4. Article 16 The obligation to bring food and drink for students as referred to in Article 13 paragraph (1) is carried out every day.

5. Article 17 To support the implementation of the program of bringing food and drink to school as referred to in Article 13 paragraph (1), then: a. prohibited from selling food, drinks, and toys in the school environment; and b. Students are prohibited from eating snacks outside the school environment during school hours.

6. Article 18 School principals are responsible for carrying out the obligation to bring food and drink by students according to this regent's regulations in their respective school environments

\section{METHOD}

The research method used in this research is the case study method. Research obtained empirical data when the study was conducted. Robert (2015: 1) "states that case studies are one of the social sciences research methods". So that the case study is very suitable to be used in research on the implementation of Perbup.

The stages of this study consisted of three stages, namely the preparatory stage, the implementation phase, the completion stage, and the research result publication stage. The population in this study were elementary school students in Purwakarta Regency. The sample 
in this study was representative of elementary school students in Purwakarta Regency with a total of 40 students. The locations of this research are SD Kahuripan Subdistrict Purwakarta, Sukatani, Jatiluhur, Tegal Waru, and Plered. The changes observed in this study are consumptive attitudes. Observations carried out through observation, interviews and documentation studies.

Case study research focuses attention on efforts to understand the behavior, perceptions, and attitudes of the research objectives. So the instrument used in this study is in the form of interview guidelines, guidelines/observation sheets of field observations, and observation sheets of the study documentation. While the technique of data collection is done by the researchers themselves. In this study, the data collection techniques used were observations, interviews, and documentation studies. The three data collection techniques are used to obtain complementary and complementary information. Data analysis begins by examining all data collected from various sources, namely from interviews, observations that have been written in the field notes, the results of recorded interviews, observations and so forth (Moleong, 1989: 209).

\section{RESULTS AND DISCUSSION}

\section{Results}

To find out the implementation of Purwakarta Regent Regulation on Bringing Food / Beverage to School, data collection was carried out using several techniques, namely observation and interviews. Observations were made on 20 students (respondents) who came from Kahuripan Elementary School. The observed behavior is a description of the 5 aspects of consumer behavior, namely: (1) The existence of a desire to consume excessively, (2) Waste, (3) Cost inefficiency, (4) recognition of needs and (5) emotional. From the 5 aspects of consumptive behavior, down to 10 statements that guide researchers in carrying out the process of observation and interview as follows:

1. Students spend money on food products,

2. Students do not force themselves to buy food products,

3. Students buy new food products,

4. Students buy one type of food product with a variety of colors,

5. Students have a lot of food products that have never been bought before,

6. Students feel satisfied if they buy a dreamed food product, even though the food product is not needed,

Implementation Of Regulations Bring Foods To School To Consumptive Behavior Of Elementary School Students In Purwakarta 79 
7. Students pay close attention to the number of money students spend to buy food products,

8. Students consider the price of food products expensive or not before buying it,

9. Students can suppress the desire to buy food products that they don't currently need,

10. Students are not easily persuaded to buy food products that are not currently needed.

From observations and interviews that we have carried out for 1 month of 40 students at SD Kahuripan, we get the following results:

1. Observed Behavior: Students spend money on food products. Observations: All students observed did not spend money on food products. Because the supplies they carry are enough to make them full and not have the desire for excessive snacks.

2. Observed behavior: Students do not force themselves to buy food products. Observation results: On average $80 \%$ of students per day do not implement themselves to buy food products, while some students still buy food but in reasonable terms and not to spend their lunches.

3. The behavior observed: Students buy food products that they are most familiar with. Observation Results: Almost all students do not buy new food products, because the conditions in the school do not have adequate stalls/canteens, food vendors are not too many and are dominated by traditional traders

4. The behavior observed: students buy one type of food product with a variety of colors. Observation Results: Most students do not buy one type of food product with a variety of colors, because the conditions in the school do not have adequate stalls/canteens, food vendors are not too many and dominated by traditional traders.

5. The behavior observed: students feel satisfied when buying a dreamed food product, even though the food product is not needed.

Observation Results: On average $80 \%$ of students feel satisfied if they buy the desired food product, even though the food product is not needed.

6. The behavior observed: students pay close attention to the amount of money students spend to buy food products.

Observations: On average $50 \%$ of students per day pay close attention to the amount of money they will spend to buy food products. 
7. The behavior observed: students consider the price of food products expensive or not before buying it.

Observations: On average $75 \%$ of students per day consider the price of food products expensive or not before they decide to buy it.

8. Observed behavior: Students can suppress the desire to buy food products that they don't currently need.

Observation Results: After the issuance of government regulations on bringing food to school, students can more suppress the desire to buy food products that they do not currently need.

9. Behavior observed: Students are not easily persuaded to buy food products that are not currently needed.

Observation Results: On average $80 \%$ of students per day do not implement themselves to buy food products, while some students continue to buy food but in reasonable terms and not to spend their lunches.

\section{Discussion}

Meeting the educational needs of students is part of a fair and equitable development in a society where individual rights are known and protected. Creating fair provisions for diverse students is the main picture of education policies in various developed countries, this has been adopted in the policies of the Purwakarta district government. The main challenge lies in the goal of equity that leads to an increasing and growing social order.

Rals (1971) in Legal Theory argues that to achieve the goal of justice in society, institutions must support the disadvantaged in terms of resource allocation. Therefore apart from the various regulations issued to support the advancement of education, the district government under the education office also has references and references to the pamong of Purwakarta's characteristic character education which is continuously published to relevant stakeholders.

\section{CONCLUSION}

The study of public policy, including the method of policy analysis, has become one of the fastest-growing fields in the science of education over the past few decades. Policy analysis appears to better understand the policy-making process and to provide policymakers with 
policy-related knowledge that can be relied upon to overcome problems in the education world with current trends.

The regent's regulation of bringing food supplies to schools contains an application and academic approach to policy formulation, emphasizing the design and choice of policy instruments. As a stage in the policy process where participants produce alternative solutions to deal with issues that enter the educational agenda on policy formulation highlighting how policy choices are made so that they can be integrated between academic values and everyday life.

The policy made by the Purwakarta district government has several advantages over other policies, including a deep understanding of education programs and priorities (which is certainly useful for adjusting the input to needs on the ground) and the ability to coordinate across government agencies. This government policy can act as a "steering machine" that focuses on responding to requests, rather than producing analysis and strategies for policy socialization, with a long-term focus that can help create an educational identity in an area based on local wisdom.

\section{ACKNOWLEDGMENTS}

Thank you to the Chancellor of IKIP Siliwangi, the vice-chancellors of IKIP Siliwangi and LPPM IKIP Siliwangi who have provided moral and material support so that we can carry out this research activity. I hope the research we have done can be useful for the progress of IKIP Siliwangi.

\section{REFERENCES}

Bagir Manan dalam W. Riawan Tjandra dan Kresno Budi Harsono, 2009, Legal Drafting Teori dan Teknik Pembuatan Peraturan Daerah, Yogyakarta:Universitas Atmajaya, hlm. 2528

Gunawan, Heri. 2012. Pendidikan Karakter Konsep dan Implementasi. Bandung: Alfabeta

Hermawan, A.W. (2014). Peran Keluarga dalam Mendidik An ak dari Usia Dini hingga Dewasa.

Moleong Lexy. 2005. Metodologi Penelitian Kualitatif. Bandung: PT Remaja Rosdakarya Peraturan Bupati Purwakarta Nomor 69 Tahun 2015 Tentang Pendidikan Berkarakter 
Journal of Elementary Education

Volume 3, Number 1, September 2019
P-ISSN: 2580-9326

E-ISSN: 2580-7714

Rohman Ahmad Abdur, Widjaja Sri Umi Mintarti. 2018. Analisis Perilaku Konsumtif Dan Perilaku Menabung Mahasiswa Penerima Beasiswa Bidikmisi Di Jurusan Ekonomi Pembangunan Fakultas Ekonomi Universitas Negeri Malang Angkatan 2014. Jurnal Pendidikan Ekonomi, Vol.11, No.2, 2018. Web Site: http://journal2.um.ac.id/index.php/jpe/index

Ridwan. (2017). pengembangan jasa pengantaran paket dan makanan untuk menumbuhkan kemandirian siswa.

Setiawan, \& Ibnu. (2016). pengaruh jasa antar makanan terhadap pembentukan sikap konsumtif siswa Sekolah Menengah Atas.

Tambunan, R. (2001). Remaja dan Perilaku Konsumtif. (Online) Tersedia di : www.asmakmalaikat.com. Diakses pada 05 Juni 2019

Tripambudi Bagas, Indrawati Endang Sri. Hubungan Antara Kontrol Diri Dengan Perilaku Konsumtif Pembelian Gadget Pada Mahasiswa Teknik Industri Universitas Diponegoro. Jurnal Empati, April 2018, Volume 7 (Nomor 2), Halaman 189

Yin. K. Robert. (2015). Studi Kasus. Desain dan Metode. PT. Rajagrafindo Persada : Jakarta. 